\title{
ISLAM DAN KEBHINEKAAN DI INDONESIA: PERAN AGAMA DALAM MERAWAT PERBEDAAN
}

\author{
Choirul Anwar \\ International Islamic University of Islamabad Pakistan \\ Email: choialquds82@gmail.com
}

\begin{abstract}
Abstrak
Perbedaan dan keberagaman merupakan sebuah keniscayaan, hal ini tidak dapat dihindari dalam kehidupan manusia. Perbedaan muncul dari berbagai aspek, seperti perbedaan suku, ras, bangsa, maupun agama. Dalam konteks Indonesia, perbedaan ini dapat dilihat dari terbentuknya negara Indonesia, dimana penduduk Indonesia terdiri dari berbagai suku, ras, dan agama, sehingga tidak jarang perselisihan pendapat terjadi antara suku satu dengan lainnya, ataupun antara agama yang satu dengan lainnya. Melalui kajian ini, penulis memfokuskan penelitian terhadap peran agama Islam dan merawat keberagaman yang ada di Indonesia. Islam mempunyai peran penting terhadap terbentuknya negara Indonesia, dan telah menjadi agama mayoritas penduduk Indonesia, meskipun negara juga mengakui lima agama lain sebagai agama resmi. Alih-alih menjadikan negara Indonesia menjadi negara Islam, umat Islam di Indonesia lebih memilih menjembatani perbedaan-perbedaan yang ada untuk menuju sebuah kesatuan sesuai dengan motto bangsa Indonesia "Bhineka Tunggal Ika". Dalam sudut pandang Islam, perbedaan adalah sebuah fitrah, yang kemudian di implementasikan oleh umat Islam Indonesia dalam kehidupan berbangsa dan bertanah air, seperti penerimaan Pancasila sebagai ideologi dan asas negara Indonesia. Sifat compatible dalam Islam inilah yang menjadikan Islam menjadi komponen penting dalam menjaga persatuan bangsa.
\end{abstract}

Kata Kunci: Islam, Kebhinekaan, Negara.

\begin{abstract}
Differences and diversity are a necessity, they cannot be avoided in human life. Differences arise from various aspects, such as differences in ethnicity, race, nation and religion. In the Indonesian context, this difference can be seen from the formation of the Indonesian state, where the Indonesian population consists of various tribes, races, and religions, so that disputes often occur between tribes, or between religious follower. Through this study, the author focuses his research on the role of Islam and caring for diversity in Indonesia. Islam has an important role in the formation of the Indonesian state, and has become the religion of the majority of Indonesian's population, even though the state also recognizes five other religions as official religions. Instead of making the Indonesian state an Islamic state, Muslims in Indonesia prefer to bridge the differences that exist to lead to unity in accordance with the Indonesian nation's motto "Unity in Diversity". In the Islamic point of view, difference is a nature, which is implemented by Indonesian Muslims, such as the acceptance of Pancasila as the ideology and principle of
\end{abstract}


the Indonesian state. The compatible nature in Islam makes Islam an important component in maintaining national unity.

Keywords: Islam, Diversity, State.

\section{Pendahuluan}

Indonesia merupakan negara dengan penduduk yang mempunyai berbagai latar belakang; ras, suku dan agama yang mempengaruhi tingkah laku dan pola pikir tiap-tiap individu. Dari segi agama, setidaknya pemerintah mengakui adanya enam agama yang telah diputuskan menjadi agama resmi bagi penduduk Indonesia, yaitu: Islam, Kathotik, Protestan, Hindu, Budha dan Konghucu. Dalam beberapa kesempatan pemeritah juga mengakui keberadaan aliran-aliran kepercayaan yang menjadi landasan hidup bagi sebagian masyarakat, akan tetapi pangakuan tersebut bukan dalam bentuk agama, tapi sebagai cultural haritage atau local wisdom, sehingga banyak dari penganut aliran kepercayaan masih mengaku menjadi pengikut dari salah satu keenam agama resmi.

Kemajemukan masyarakat Indonesia menjadi daya tarik tersendiri, meskipun tidak dipungkiri bahwa aspek tersebut juga mempunyai bagian negative yang perlu diwaspadai, khususnya dalam hal religious diversity. Aspek ini begitu penting dan sangat sensitive mengingat setiap agama mempunyai eksklusivitas dogma yang diajarkan oleh masing-masing agama, sehingga apabila ada salah satu penganut agama menyinggung agama lain, maka efek yang terjadi adalah anggapan penistaan agama yang telah diatur dalam KUHP 156a dan UU No. 1 PNPS tahun 1965 tentang Pencegahan Penyalahgunaan dan/atau Penodaan Agama (selanjutnya disebut UU Penodaan Agama).

Dalam konteks demokrasi bernegara saat ini, umat Islam mempunyai tantangan yang cukup besar. Setelah muncul stigma negatif radikalisme dalam Islam dengan memunculkan kelompok-kelompok garis keras yang mengaku muslim, sekarang muncul stigma baru bagi umat Islam, yaitu anti-kebhinekaan dan anti-pancasila, sehingga muncul kelompok-kelompok yang mengaku lebih "pancasilais" "bhinekais" bahkan mengaku "saya Indonesia". Stigma negative tersebut kemudian didukung oleh laporan tindakan intoleransi yang dilakukan oleh "kelompok umat Islam, atau figur umat Islam". Nampaknya stigma negatif anti-pancasila dan kebhinekan yang labelkan kapada kelompok umat Islam mempengaruhi kebijakaan pemerintah, sehingga memunculkan 
Perppu (Peraturan Pemerintah Pengganti Undang-Undang) No.2 tahun 2017 tentang organisasi masyarakat, akibat munculnya Perppu tersebut, setidaknya ada enam ormas yang sudah dan akan dibubarkan terkait ideologi yang dianggap tidak sesesuai dengan Pancasila dan mengancam kebhinekaan Indonesia, yaitu: Hizbut Tahrir Indonesia, Aliansi Nasional Anti Syiah, Jamaah Ansarut Tauhid, Majelis Mujahidin Indonesia, Forum Umat Islam, dan Front Pembela Islam. Dari segi individual figure ada beberapa orang yang dianggap mengancam kebhinekaan Indonesia oleh beberapa kelompok, yaitu: Ustadz Bachtiar Natsir, Habib Rizieq Shihab, dan Ustadz Felix Siaw.

Terlepas dari apakah Perppu tersebut digunakan hanya untuk kelompok umat Islam atau tidak, tapi pada kenyataannya sampai saat itu hanya ormas Islam saja yang target dari Perppu tersebut. Terlepas dari apakah tuduhan itu benar atau tidak, langkah preventif pemerintah untuk menjaga ideologi dan keutuhan bangsa perlu dilakukan.

Dalam laporan lain tidak hanya keenam ormas tersebut yang mendapat label antiPancasila dan kebhinekaan, bahkan ormas besar seperti NU dan Muhammadiyah tidak lepas dari tuduhan tersebut, seperti dalam laporan Human Rights Watch $^{1}$ yang menyatakan bahwa kedua ormas tersebut bersikap inkonsistensi terhadap minoritas agama dalam kasus Syiah di Indonesia. MUI pun tidak lepas dari tuduhan tersebut karena lembaga inilah yang mengajukan kepada pemerintah mengenai kebijakan tentang agama, sehingga sikap ormas dan lembaga tersebut dinilai tidak menghargai kebhinekaan yang ada di Indonesia

Berangkat dari problematika diatas, melalui tulisan ini penulis bertujuan mencari titik temu atas kesalahpahaman mengenai hubungan Islam dan kebhinekaan di Indonesia. Tulisan ini berusaha menjawab pertanyaan apakah Islam bertentanggan dengan ideologi Pancasila dan semangat kebhinekaan di Indonesia yang saat ini sering tuduhkan kepada kelompok-kelompok Islam. Pada tulisan ini penulis membagi pembahasan menjadi empat bagian: Pertama, Kebhinekaan dan toleransi dalam teks Islam. Kedua, Islam dan Politik Indonesia. Ketiga, Islam dan kebhibekaan Agama di Indonesia. Keempat, kesimpulan.

\footnotetext{
${ }^{1}$ Laporan Human Right Watch, Atas Nama Agama Pelanggaran Terhadap Minoritas Agama di Indonesia, (USA: Human Rights Watch, 2013), h. 17.
} 


\section{Kebhinekaan dan Toleransi dalam Teks Islam}

Kebhinekaan dan toleransi bukanlah hal baru dalam Islam. 10 abad sebelum lahirnya The Toleration Act di Eropa pada tahun 1689 Islam telah lebih dulu mengaplikasikan toleransi terhadap berbedaan. Bukti otentik mengenai hal tersebut dapat dilihat dalam piagam Madinah yang menyatakan bahwa semua golongan agama dan suku yang berada di Madinah mempunyai hak, perlakuan dan kewajiban yang sama, tanpa harus memaksakan kehendak kepada golongan lain baik dari segi keagamaan maupun sosial. Pengakuan persamaan hak tersebut tidak lepas dari teks yang mendasari Rasulullah dalam menyikapi sebuah perbedaan.

Dalam konteks kesukuan dan kebangsaan, Islam sangat mengakui keberagaman tersebut, bahkan melalui surah Al-Hujurāt:13

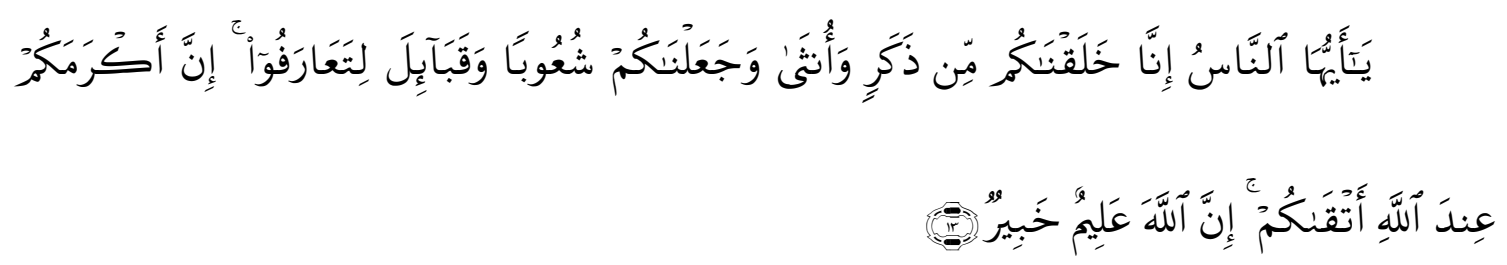

Allah menyampaikan secara jelas bahwa manusia diciptakan berbangsa-bangsa dan bersuku-suku agar saling mengenal, yang dalam tafsir Ibnu Katsir dijelaskan bahwa Syu' $\bar{u} b$ berarti orang non-Arab, dan Qabāil adalah orang Arab. ${ }^{2}$ Pendapat yang hampir sama juga dikemukaan oleh Imam At-Thabari dalam tafsirnya yang mengatakan bahwa Syu'ūb ditafsirkan sebagai keturunan jauh (nasaban ba'̄odan) dan Qabāil adalah keturunan yang dekat (nasaban qarīban). ${ }^{3}$

Keberagaman merupakan sunnatullah yang tidak bisa dirubah, bagi seorang muslim hal ini menjadi ujian atas apa yang telah diberikan Allah, dan hal ini tersirat dalam surah al-Maidah: 48.

${ }^{2}$ Abul Fida' Ismail bin Umar bin Katsir Al-Qursyi Ad-Dimasqi, Tafsir ul-Qurān al-Adzīm, (Darut Taibah: 1999), h. 385. Edisi Maktabah Syamilah

${ }_{3}^{3}$ Abu Ja'far at-Thabari, Jami'ul Bayān fì Ta'wīlil Qurān, (Muassatur Risalah, 2000), h. 309. Edisi Maktabah Syamilah 


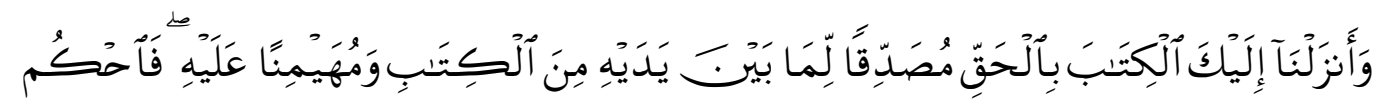

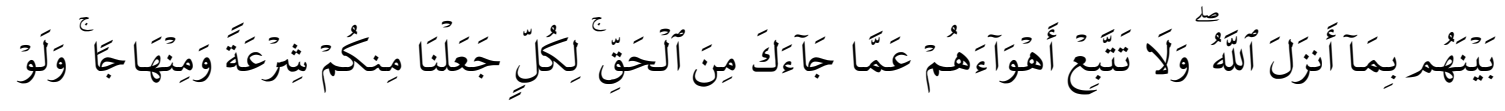

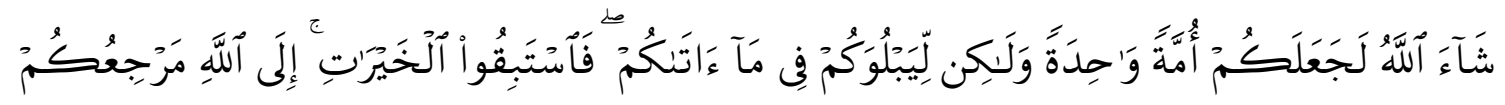

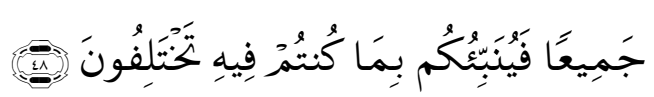

Terlepas dari polemik penafsiran kalimat likullin ja 'alnā syir'atan wa minhājan ${ }^{4}$ terdapat persamaan penafsiran bahwa jika Allah berkehendak maka Dia akan menjadikan manusia menjadi satu umat saja. Jika ditelusuri lebih jauh lagi maka akan ditemukan bahwa pengakuan keberagaman tersebut bukan hanya berlaku pada suku dan bangsa, tapi juga menyangkut keberagaman agama. Dan hal ini sangat jelas disampaikan dalam surah Yunus: 99.

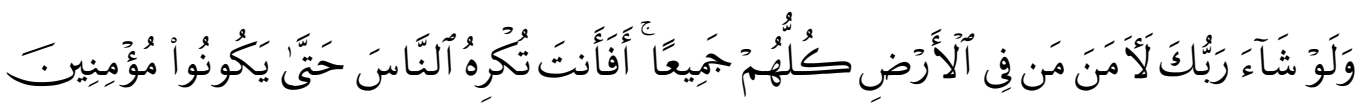

Yang artinya “ Dan jika Tuhanmu menghendaki, tentulah beriman semua orang yang dimuka bumi seluruhnya. Maka apakah kamu hendak memaksa manusia supaya mereka menjadi orang-orang yang beriman semuanya?".

Dalam surah al-Kāfirūn: 6 disebutkan lakum dīnukum waliya-d-dīn yang dalam asbāb-n-nuzul merupakan bentuk jawaban Rasulullah terhadap rayuan kafir Quraisy untuk “barter of belief”. Meskipun ayat ini turun sebagai bentuk penolakan, namun secara tidak langsung ayat ini juga menegaskan bahwa ajaran Islam tidak boleh dilakukan dengan bujuk rayu dan tipu muslihat seperti yang dilakukan kaum Quraisy. Selain itu ayat ini juga memberikan gambaran toleransi dalam Islam yaitu dengan tidak

${ }^{4}$ Dalam tafsir at-Thabari disebutkan bahwa penafsiran kalimat tersebut terbagi menjadi 2: Pertama, setiap agama mempunyai syariah dan manhaj. Kedua, makna kalimat tersebut adalah agama itu satu akan tetapi syariahnya berbeda. Ibid, h. 385 . 
mencampuradukan iman dan ritual Islam dengan agama lain, tapi dengan menghargai eksistensi agama lain. Dan jika ditelaah lebih dalam lagi maka akan didapatkan bahwa keseluruhan surah al-Kāfirūn merupakan konsep toleransi antar agama pertama yang pernah ada, dimana kesimpulan dari surah tersebut adalah setiap agama mempuyai hak untuk melaksanakan ibadahnya dan setiap agama tidak boleh memaksakan ajarannya kepada umat lain, termasuk Islam.

Pemaksaan keimanan dalam Islam merupakan hal tidak dilegalkan dalam berdakwah dan ini jelas tertulis di surah al-baqarah: 256 yang menyatakan lā iqrāha fi-ddīn. Dalam riwayatnya ayat ini turun karena datang seorang muslim anshar yang mempunyai dua anak laki-laki, namun keduanya lebih memilih beragama nasrani, muslim anshar tadi kemudian datang kepada Rasulullah dan mengadukan masalahnya "wahai Rasulullah, apakah saya hanya diam saja menyaksikan sebagian dari kami masuk neraka?” kemudian turunlah ayat ini dan akhhirnya muslim anshar melepaskan kedua anaknya. ${ }^{5}$

Islam tidak memaksakan urusan keimanan karena sejatinya iman adalah attasdīqu bil-qalb wal iqrār bil lisan wal 'amalu bil jawārih (meyakininya dengan hati, mengucapkanya dengan lisan, dan mengamalkannya dengan anggota badan) sehingga harus diikuti dengan perasaan tunduk dan taat. Dan tentunya kedua hal tersebut tidak akan terwujud dengan paksaan. Agaknya ayat tersebut juga bisa menjadi hujjah bagi muslim kepada orang-orang yang mengatakan bahwa Islam tersebar karena perang, pedang, dan kekerasan.

Setiap agama mempunyai tuhannya masing-masing, dalam Kristen ada Yesus, bagi Hindu ada Trimurti (Brahman, Wisnu dan Siwa) dan sebagainya, Budha dengan Triloka (Sakyamuni, Bhaisajyaguru, Amitabha) dan sebagainya, Konghucu dengan Tridharma ( $\mathrm{Lao}$ zi, Kong $\mathrm{Hu} \mathrm{Cu}$, dan Sakyamuni). Dalam Islam meskipun muslim menyakini bahwa Tuhan hanyalah Allah, tapi bukan berarti melecehkan ataupun menghina tuhan agama lain diperbolehkan. Surah al-An'am:108

\footnotetext{
${ }^{5}$ Al-Wāhidī, Asbābu Nuzūlil Qurān, h. 26. Edisi Maktabah Syamilah
} 


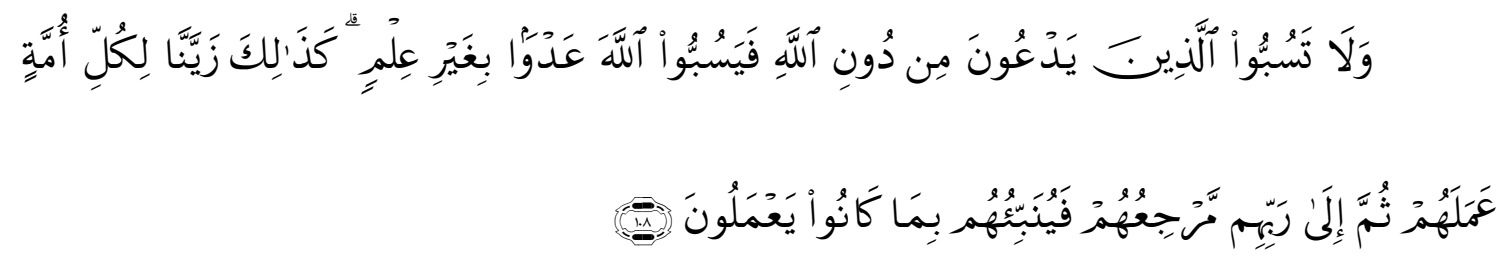

"Dan janganlah kamu memaki sembahan-sembahan yang mereka sembah selain Allah, karena mereka nanti akan memaki Allah dengan melampaui batas tanpa pengetahuan. Demikianlah Kami jadikan setiap umat menganggap baik pekerjaan mereka. Kemudian kepada Tuhan merekalah kembali mereka, lalu Dia memberitakan kepada mereka apa yang dahulu mereka kerjakan"

Ayat diatas dengan jelas melarang muslim untuk memaki sembahan agama lain selain Allah, hal ini dilakukan agar menghindari konflik sosial-agama yang akan terjadi jika antar umat beragama saling memaki tuhan masing-masing agama. Inilah bentuk toleransi Islam dalam menjada kerukunan antar umat beragama.

Doktrin agama Islam yang tercantum dalam ayat-ayat diatas tentunya harus menjadi landasan teologis yang memberikan kemerdekaan dan kebebasan beragama dalam Islam. Seorang Muslim tidak dibenarkan untuk memaksa non-Muslim baik secara pribadi maupun komunal untuk memeluk agama Islam. Secara logika, bagi non-Muslim dibebaskan untuk menganut dan melaksanakan ajaran agamanya masing-masing. Doktrin agama Islam dalam ayat-ayat tersebut, pada satu sisi, harus menjadi pedoman etika bagi umat Muslim dalam menyampaikan ajaran agama dan, pada sisi lain, menjadi pedoman etika dalam pergaulan seorang Muslim dengan komunitas agama yang lain.

Islam tidak melarang muslim untuk bermuamallah dengan non-muslim dalam hal yang berkaitan dengan urusan dunia, tidak ada batasan bahwa muslim hanya boleh bermuamalah dengan muslim saja. Bahkan Islam mengajarkan agar bermuamalah dengan siapan tanpa memandang agama, ras dan suku disertai dengan sikap adil meskipun terhadap orang ataupun kelompok yang dibenci. Dalam surah al-Maidah: 8 disebutkan bahwa seorang mukmin hendaklah menegakan kebenaran karena Allah dan menjadi saksi dengan adil, kemudian dilanjutkan dengan larangan agar kebencian terhadap suatu kaum tidak menjadikan umat muslim berlaku tidak adil terhadap kaum tersebut. 
Dua surat terakhir sangat jelas menerangkan bagaimana seorang muslim harus mensikapi sebuah berbedaan agama. Tidak ada dalam kitab agama yang lain yang secara terang-terangan menunjukan sebuah penghormatan kepada agama lain (dalam konteks sosial) sebagaimana yang disampaikan dalam Qurān. Oleh karena itu tekanan dan pemaksaan dalam bentuk apa pun (secara fisik maupun psikis, tertutup ataupun terbuka, baik itu langsung ataupun tidak langsung,) untuk memaksa pribadi atau komunitas nonMuslim agar memeluk agama Islam adalah sebuah perbuatan yang menyalahi doktrin agama Islam dan tidak dibenarkan. Karena, secara doktrin teologi agama Islam, tekanan dan paksaan demikian pada satu sisi sangat bertentangan dengan Alqur'an sendiri dan, pada sisi lain, sangat bertentangan dengan prinsip-prinsip yang telah disepakati sabagai Hak Asasi Manusia.

\section{Islam Dan Politik Indonesia}

Agama dalam banyak pernyataan dianggap sebagai intrumen ketuhanan yang digunakan untuk memahami dunia. Dibandingkan dengan agama lain, Islam merupakan agama paling mudah menerima premis tersebut, hal ini karena sifat Islam yang "omnipresence" (hadir disegala aspek). Ini menjadi pandangan yang mengakui bahwa kehadiran Islam diperlukan sebagai "panduan moral bagi manusia" ${ }^{6}$. Pandangan ini kemudian menjadi landasan bagi sejumlah muslim bahwa Islam mencakup tata cara hidup secara total, dan bagi sebagian kelompok hal ini menjadi pendorong untuk diberlakukanya Syarī'ah (hukum Islam), karena Islam memberikan pemecahan terhadap semua permasalahan. ${ }^{7}$ Islam dan politik mempunyai hubungan yang erat, apabila keduanya mampu dipahami sebagai sarana untuk mengatur kebutuhan hidup rnanusia secara menyeluruh. Islam tidak hanya digunakan sebagai kedok untuk mendapat kepercayaan dan pengaruh dari masyarakat semata. Politik juga tidak sekedar digunakan sebagai sarana memperoleh posisi dan otoritas formal dalam struktur kekuasaan. ${ }^{8}$

Pengertian politik (al-siyasah) dalam fiqih Islam menurut ulama Syafi'iyah (Madzhab Fiqih yang dianut oleh mayoritas Muslim di Indonesia) mengatakan bahwa

\footnotetext{
${ }^{6}$ Bahtiar Effendy, Islam dan Negara Transformasi Gagasan dan Praktik Politik Islam di Indonesia, (Jakarta: Yayasan Abad Demokrasi,2011), h. 7.

${ }^{7}$ Ibid, h. 8.

${ }^{8}$ KH.MA. Sahal Mahfudh, Nuansa Fiqih Sosial, (Yogyakarta: LKIS, 1994), h. 151.
} 
politik harus sesuai dengan syari'at Islam, dimana setiap upaya, sikap dan kebijakan dilakukan guna mencapai tujuan umum prinsip syari'at, yaitu (1) Untuk memelihara agama. (2) Memelihara rasionalitas. (3) Memenuhi Kebutuhan Jasmani dan Rohani. (4) Menjamin keamanan harta. (5) Memelihara Keturunan. ${ }^{9}$ Dalam konteks Indonesia, hubungan Islam dan politik dapat dilihat dalam penerimaan Pancasila sebagai ideologi bangsa satu-satunya asas bernegara. Penerimaan ini tidak berarti menghapus cita-cita Islam dan menghilangkan unsur Islam dalam percaturan politik di Indonesia. Sejauh mana unsur-unsur dalam Islam mampu menjadi inspirasi dalam percaturan politik, tergantung pada kemampuan kalangan muslimin muncul dengan penampilan baru yang dapat mengembangkan kekayaan pengetahuan sosial dan politik untuk menganalisa dan memetakan perubahan sosial. ${ }^{10}$

Sejak awal kemerdekaan Indonesia, Islam telah mengambil bagian dalam perpolitikan, sehingga pembentukan partai politik Islam menjadi salah satu upaya agar agama (Islam) juga berperan aktif dalam pengambilan kebijakan negara, dan tentu ini tidak terlepas dari "investasi” terbanyak umat Islam dalam memperjuangkan kemerdekaan Indonesia. Untuk merepresentasikan suara umat Islam dalam dunia politik maka lahirlah Masyumi pada tahun 1945 yang didukung oleh NU, Muhammadiyah dan ormas Islam lainnya. ${ }^{11}$ Menurut Porter lahirnya Masyumi juga tidak terlepas sebagai bentuk perlawanan terhadap partai-partai yang dianggap mengancam eksistensi muslim, seperti PNI dan PKI. ${ }^{12}$

Pembentukan dan pendeklarasian Masyumi sebagai satu-satunya partai Islam di Indonesia terjadi pada Muktamar Islam Indonesia di Yogyakarta pada tanggal 7-8 November 1945. Tujuan Masyumi sebagai satu-satunya partai Islam ternyata tidak tercapai secara penuh karena pada tahun yang sama organisasi Persatuan Tarbiyah Islamiyah (Perti) tidak bersedia untuk bergabung untuk mendukun Masyumi dan kemudian membentuk partai sendiri. ${ }^{13}$

${ }^{9}$ Ibid, h. 152-153.

${ }^{10}$ Ibid, h. 151.

${ }^{11}$ Donald J. Porter, Managing Politics and Islam in Indonesia, (London:Routledge Curzon,2005), h. 40 .

${ }^{12}$ Ibid, h.40.

${ }^{13}$ M. Ali Haidar, Nahdlatul Ulama dan Islam di Indonesia Pendekatan Fikih dalam Politik, (Jakarta: Gramedia Pustaka Utama, 1994), h. 120. 
Masuknya Islam dalam dunia politik Indonesia seharusnya tidak perlu dikhawatirkan akan merusak ideologi bangsa (Pancasila) dan bukti mengenai hal tersebut sudah ada sejak awal berdirinya negara yaitu dengan diterimanya revisi isi Pancasila oleh golongan Islam meskipun harus menghilangkan tujuh kata pada sila pertama (dengan kewajiban menjalankan Syari'at Islam bagi pemeluk-pemeluknya). Kesepakatan ini kemudian dikenal dengan Piagam Jakarta. ${ }^{14}$ Bagi tiap kelompok yang ikut dalam perumusan konstitusi diawal kemerdekaan, tentu ketetapan dasar negara ini menjadi begitu penting. Hal ini kerena dasar negara menjadi pijakan utama dalam menentukan arah dan cara penyelenggaraan negara. ${ }^{15}$ Keputusan yang diambil oleh tokoh-tokoh muslim seperti Muhammad Natsir, Buya Hamka, Kasman Singodimejo, dan Agus Salim dalam perumusan ideologi negara menunjukan sikap toleransi terhadap eksistensi golongan lain.

Pada pemilu pertama tahun 1955 kombinasi partai-partai Islam memperoleh 43 persen kursi parlemen dan 39.3 persen dari hasil pemilu, kemudian disusul oleh PNI 22.3 persen dan PKI 16 persen. ${ }^{16}$ Perolehan tersebut tentu menjadi pertimbangan bagi lawan politik lainnya khususnya yang berhaluan nasionalis ataupun komunis pada masa itu, sehingga perlu dilakukan suatu strategi untuk melemahkan kekuatan politik tersebut. Dan tampaknya strategi itu berhasil dengan dibubakanya Masyumi pada 17 Agustus 1960 karena dituding terlibat dalam pemberontakan Permesta (Perjuangan Rakyat Semesta), PPRI (Pemerintahan Revolusioner Republik Indonesia), dan DI/TII (Darul Islam/Tentara Islam Indonesia).

Sebagai negara dengan sistem demokrasi maka sudah seharusnya jika kebijakan negara berdasarkan persetujuan mayoritas karena seperti yang disampaikan oleh Muhammad Natsir “ Prinsip demokrasi itu: Pertama, golongan yang berkuasa harus mendapatkan persetujuan dari golongan terbesar (mayoritas); dan kedua, golongangolongan kecil terjamin hak hidupnya dalam masyarakat”. ${ }^{17}$ Kutipan tersebut memperlihatkan bagaimana seharusnya negara demokrasi yang identik dengan mayoritas

\footnotetext{
${ }^{14}$ Michel Picard, "Agama Adat dan Pancasila", The Politics of Religion in Indonesia, (New York: Routledge, 2011), h. 12.

15 Ahmad Suaedy, Alamsyah M. Dja'far dkk, Islam dan Kaum Minoritas : Tantangan Kontemporer, (Jakarta: the Wahid Institute,2012), h. 58

16 Jusuf Wanandi, “ Islam in Indonesia: Its History, Development and Future Challenges”, AsiaPacific Review, vol. 9, No. 2, 2002, h. 106

${ }^{17}$ Ahmad Suaedy, Alamsyah M. Dja'far dkk, Islam dan Kaum..., h. 59.
} 
harus mempertimpangkan aspirasi mayoritas (umat Islam), dan dilain pihak mayoritas harus menjamin hak hidup kelompok minoritas. Sikap lebih jelas tentang perlindungan kaum minoritas dalam politik Islam disampaikan oleh KH. Agus Salim melalui sebuah artikel: "Dalam karangan ini kita hendak menunjukan minat kepada kemerdekaan agama itu. Bagaimana kemerdekaan itu harus dipahami dalm negara kita, yang berdsarkan kepercayaan kepada Ketuhanan yang Mahaesa. Dapatkah dengan asas negara itu kita mengakui kemerdekaan keyakinan agama yang mengakui Tuhan terbilang atau terbagibagi? Tentu dan pasti!" ${ }^{18}$ pernyataan tersebut menunjukan ketegasan sikap dalam melindungi hak-hak kaum minoritas.

Dalam konteks yang sedang berkembang saat ini, tidak mengejutkan jika umat muslim Indonesia ingin mendasarkan seluruh aspek kehidupan sosial, ekonomi, dan politik kepada ajaran Islam, yang tentunya akan ada keterbatasan dalam praktiknya. Ekpresi kebangkitan tersebut dapat ditemukan dengan istilah-istilah yang muncul belakangan ini seperti revivalisme Islam, kebangkitan Islam, revolusi Islam ${ }^{19}$, atau yang masih segar dengan gerakan 212. Dalam istilah terakhir, meskipun saat ini masih berfokus kepada ekonomi keumatan, tapi tidak menutup kemungkinan jika gerakan tersebut menjadi salah satu politic power bagi umat Islam, dan itu sudah terbukti dalam pilkada DKI. Umat Islam sebagai mayoritas di Indonesia sudah tentu mempunyai peran yang signifikan dalam menentukan cara pandang dan kebijakan negara. Dan yang terjadi saat ini peran tersebut dikhawatirkan oleh sebagian kelompok akan mengihilangkan "hakhak" mereka dalam bernegara dan berbangsa.

Menurut Giora Elizar dari The Hebrew University of Jerusalem dalam sebuah diskusi di Universitas Washington menyatakan bahwa politik identitas (muslim) yang sekarang marak dilakukan sebagai branding dan alat pemenangan pemilu di Indonesia jika dilihat sesaat seolah-olah akan menampilkan gambaran demokrasi yang bergerak mundur. Namun, jika dilihat lebih seksama dan dari horison sejarah yang lebih luas maka justru menunjukan bahwa demokrasi Indonesia bergerak maju dan mantap. ${ }^{20}$ Pernyataan

${ }^{18}$ Ibid, h. 64.

${ }^{19}$ Effendy, Islam dan Negara, h. 8.

${ }^{20} \mathrm{https} / / /$ news.detik.com/kolom/d-3485150/kekalahan-ahok-islam-politik-dan-narasi-demokrasidi-indonesia. 
ini justru kontradiktif dengan beberapa pengamat politik dalam negeri yang menyatakan demokrasi Indonesia mengalami kemunduran.

\section{Antara Islam dan Kebhinekaan Indonesia}

Bhinneka Tunggal Ika yang berarti meskipun berbeda-beda tapi tetap satu merupakan motto resmi negara Republik Indonesia. Motto ini muncul dalam lambang Garuda Pancasila pada sebuah gulungan yang dicengkeram dengan kaki Garuda. Motto ini muncuk secara eksplisit pada pasal 36A dalam Undang-Undang Dasar yang menyebutkan bahwa lambang nasional negara Republik Indonesia adalah Garuda Pancasila dengan motto Bhinneka Tunggal Ika. ${ }^{21}$

NKRI yang telah dibangun oleh tokoh-tokoh Islam belakangan ini mendapatkan tantangan yang serius. Banyaknya kasus radikalisme berlatar belakang agama tampak identik dengan perilaku intoleran terhada perbedaan, ekstrim dalam menanggapi masalah, lalu menjadikan kekerasan sebagai jalan untuk menyelesaikan masalah. Sampai saat in masih ada sebagian kelompok masyarakat yang belum mampu menerima arti perbedaan, yang akibatnya perbedaan dipaksakan untuk melebur menjadi satu pemahaman yang dibangun oleh kelompok tertentu.

Tragedi kekerasan kelompok radikalis (dalam hal ini bukan hanya kelompok yang mengatasnamakan "Islam", tapi juga kelompok-kelompok lain yang memaksakan pemahaman) meninggalkan pesan bahwa pemahaman merekalah yang paling benar. Padahal perbedaan seyogyanya menjadi sebuah dinamika kehidupan yang perlu didialogkan, tapi justru menjadi alasan untuk melakukan pemaksaan terhadap kelompok yang kontra. Akibatnya perbedaan selalu identik dengan kekerasan sebagai solusinya.

Dalam pandangan Gus Dur, kemunculan kelompok-kelompok Islam Radikal terjadi karena dua faktor. Pertama, karena penganut Islam Radikal ini mengalami kekecewaan akan "ketertinggalan" umat Muslim terhadap kemajuan Barat dan pengaruh budaya mereka terhadap dunia Islam. Kerana ketidak mampuan kelompok radikal ini dalam membendung pengaruh Barat maka kelompok ini memilih mengunakan tindakan kekerasan sebagai tameng terhadap meterialistik budaya Barat. 1999), h.81.

21 Mahkamah Konstitusi, Undang-Undang Dasar Republik Indonesia Tahun 1945, (Jakarta: 
Kedua, kemunculan kelompok-kelompok Islam Radikal ini terjadi karena pendangkalan agama di kalangan umat Islam. Kelompok ini mencukupkan diri dengan penafsiran keagamaan yang didasarkan pada pemahaman mereka secara literal atau tekstual. Tidak sedikit dari tokoh-tokoh kelompok ini yang memiliki hafalan Al Qur'an dan Hadits dalam jumlah besar dan mengagumkan. Akan tetapi pemahaman mereka terhadap substansi ajaran dan nilai-nilai Islam sangat lemah karena tanpa mempelajari pelbagai penafsiran yang ada, seperti kaidah-kaidah dalam ushul fiqh, maupun variasi penafsiran terhadap teks-teks yang ada. ${ }^{22}$

Dalam Islam berbedaan merupakan sebuah fitrah manusia, pemaksaan terhadap sebuah sebuah perbedaan justru melanggar fitrah tersebut, apalagi melakukan kekerasan untuk memaksakan kehendak menjadi hal yang kontradiktif dengan makna Islam sendiri. Menurut bahasa, kata Islam berarti tunduk, patuh, berserah diri, dan damai. Jadi karakteristik dan watak dasar Islam sebenarnya adalah gagasan komprehnsif tentang perlunya perdamaian dalam hidup dan kehidupan manusia. Islam diturunkan sebagai agama untuk tujuan mewujudkan salam (keselamatan), kedamaian dan perdamaian. ${ }^{23}$ Dengan demikan maka segala bentuk tindak kekerasan terorisme, anarkisme dan ketidak setujuan terhadap perbedaan sebenarnya bertentangan dengan watak dasar, visi dan misi agama Islam.

Islam pada dasarnya memandang manusia dan kemanusian secara positif dan optimistis. Dalam pandangan Islam, manusi berasal dari nenek moyang sama yaitu keturnan Adam dan Hawa. Meskipun berasal dari rahim yang sama, akan tetapi kemudian manusia menjadi berbeda suku, kaum, bangsa, negara, lengkap dengan peradaban dan kebudayaan masing-masing. Semua perbedaan ini kemudian mendorong untuk saling mengenal dan memberikan apresiasi satu dengan lainnya. perbedaan dalam manusia, menurut pandangan Islam bukan dikarenakan ras, kulit, dan bangsa, tapi hanya tergantung tingkat ketakwaan masing-masing dan tertulis dalam al-Hujurat ayat 13. Inilah yang

\footnotetext{
${ }^{22}$ Abdurrahman Wahid, Islamku Islam Anda Islam Kita, (Jakarta :The Wahid Institute, 2006), h. xxviii.

${ }^{23}$ Faisal Ismail, Republik Bhineka Tunggal Ika: Mengurai Isu-Isu Konflik, Multikulturalisme, Agama dan Sosial Budaya, (Jakarta:Puslitbang Kehidupan Beragama, 2012), h. 3.
} 
seharusnya menjadi dasar umat Islam untuk membangun ukhuwah insaniyah atau ukhuwah basyariyah. ${ }^{24}$

Islam sebagai agama damai yang menurut watak dan kodratnya harus disampaikan oleh para pemeluknya dengan prinsip-prinsip yang telah diajarkan Rasulullah dalam surah an-Nahl: 125 yaitu dengan bijaksana, pelajaran yang baik, dan apabila perlu perbedatan, maka berdebatlah dengan baik. Inilah karakteristik Islam santun dalam menyikapi berbedaan karena tentu perdebatan akan timbul karena adanya perbedaan. Sikap seperti ini perlu dikedepakan mengingat tidak akan ada penerimaan dalam perbedaan jika disampaikan dengan dengan bersikap keras dan kasar, bahkan itu akan memperlebar jarak perbedaan antara satu kelompok dengan lainya dan ini tertulis dalam surah āli-Imrān: 159 .

Prinsip-prinsip kebebasan, hak, menghormati perbedaan telah lama dipraktikan oleh Islam sejak zaman Rasulullah. Implementasi prinsip-prinsip tersebut dapat dilihat dalam piagam Madinah yang dikenal dalam sejarah sebagai konstitusi tertulis pertama di dunia yang membuat dasar-dasar toleransi, harmoni dan kebebasan bagi setiap penduduk untuk mendapatkan hak-hak dasar manusia. Pada pembukaan piagam Madinah secara jelas disebutkan bahwa " Ini adalah piagam dari Muhammad S.A.W diantara kaum mu'minin dan muslimin dari Quraisy dan Yatsrib, dan orang-orang yang mengikuti mereka, menggabungkan diri dan berjuang bersama mereka" 25 yang kemudian dilanjutkan dengan isi pertama piagama dengan menyatakan bahwa "Sesungguhnya mereka satu umat, lain dari (komunitas) manusia lainya" ${ }^{26}$ pernyataan pertama menunjukan bagaimana Rasulullah mengakui eksistensi umat lain, dan menghargai perbedaan tersebut dengan istilah satu umat. 47 isi Piagam Madinah jika disimpulkan akan mendapatkan bahwa setiap individu dan kelompok yang berada di kota Madinah mendapat jaminan hak, kebebasan, dan perlindungan jiwa, harta dan agama.

Konsep "Bhineka Tunggal Ika" sebagai identitas bangsa Indonesia yang kalimatnya diadopsi dari filsafat Nusantara (pada masa Kerajaan Majapahit) untuk menyatukan bangsa sejatinya tidak terlalu perbeda (untuk tidak dikatakan sama) dengan

14.

${ }^{24}$ Ed. Elza Peldi Taher, Merayakan Kebebasan Beragama,(Jakarta: Democracy Project, 2011), h.

${ }^{25}$ Terj. Piagam Madinah, h. 15.

${ }^{26}$ Ibid, h. 15. 
isi pertama Piagam Madinah. Kemajemukan dan keragaman sudah tentu membutuhkan "simbol" pemersatu agar tidak terjadi konflik yang merugikan individu, kelompok, dan negara secara lebih luas.

Dalam konteks hubungan antar agama di Indonesia, terbentuknya Pancasila dapat dikatakan sebagai perwujudan dari keinginan untuk mengembangkan kalîmatun sawâ dalam Islam, yaitu pengambilan kebijakan yang bersifat win win solution untuk menjembatani perbedaan pendapat dalam pembentukan Pancasila. Hasil penerimaan Pancasila itu, sangat jelas menunjukan bahwa para pemimpin Islam sangat mengutamakan kerukunan dan integritas nasional dibandingkan hanya memikirkan kepentingan umat muslim belaka. Dalam pandangan mayoritas umat muslim Indonesia, penerimaan Pancasila menjadi hadiah terbesar umat Islam untuk menjaga kesatuan dan keutuhan bangsa dan negara Indonesia yang majemuk dari segi agama, suku, adat istiadat, dan lain-lain. ${ }^{27}$

Sejatinya dalam konsep kebhinekaan, Islam sebagai agama mayoritas telah berhasil menyatukan berbagai suku yang tersebar di kepulaian Nusantara dan menjadi salah satu dasar persatuan yang penting. Dan jika melihat kebelakang dalam sejarah Indonesia, Islam tidak hanya berfungsi sebagaiagama penyangga status quo, tetapi juga sebagai agama untuk memobilisasi massa untuk menggerakan perubahan. ${ }^{28}$ Dan peran terakhir masih berlaku khusunya dalam peristiwa reformasi di Indonesia.

Menurut Azhar dalam Fikih Kebinekaan, penerapan nilai-nilai Islam di Indonesia yang plural ini telah banyak dilakukan, khususnya yang mengunakan pendekatan kultural-substansial-diferensial yakni nilai-nilai syariah yang universal ditransformasikan menjadi sebuah fikih kenegaraan (undanga-undang) maupun fikih kedaerahan (perda-perda) yang secara objektif bisa diterima oleh semua golongan, mazhab dan sekte masyarakat muslim, termasuk juga non-muslim. Pendekatan ini dnilai berhasil dalam mengaplikasikan nilai-nilai Islam dalam kehidupan berbangsa dan bernegara, bahkan nilai-nilai tersebut mampu memunculkan institusi. ${ }^{29}$ Sebagai contoh: Pertama, Lembaga KPK, ICW, Transparasi Masyarakat International dan sejenisnya;

\footnotetext{
${ }^{27}$ Ed. Elza Peldi Taher, Merayakan Kebebasan Beragama, h. 23.

28 Naupal, "Agama dan Kebhinekaan Indonesia: Membaca Peran Agama Sebagai Sistem Pertahanan Kultur dan Harmoni”, makalah FIB UI, h. 510.

${ }^{29}$ Muhammad Azhar, "Epistemologi Islam Kontemporer Sebagai Basis Fikih Kebinekaan”, Fikih Kebinekaan, (Bandung: Mizan Pustaka, 2015), h. 108.
} 
secara tidak langsung merupakan objektivitas ayat Qurān al-Māidah:38 (al-sâriqu wa alsâriqatu faqtha' $\hat{u}$ aydiyahumâ). dalam penjegahan pencurian/korupsi. Kedua, keberadaan YLKI yang merupakan implementasi objektivitas al-Baqarah:168 (Kullu min rizqillâh halâlan thayyiban). Ketiga, eksistensi Komnas HAM, Komnas Perempuan dan Anak (terkait kasus muslim Rohingya dll) yang merupakan implementasi dari Qurān tentang keadilan, hak asasi manusia, dan larangan membunuh terhadap nyawa satu manusia sekalipun seperti yang tertulis dalam al-Māidah:32 (barang siapa yang membunuh seorang, bukan karena seorang itu membunuh orang lain, atau bukan karena membuat kerusakan di bumi, maka seakan-akan ia telah membunuh manusia seluruhnya) dan sebaliknya jika menjaga kehidupan seorang maka seakan menjaga kehidupan manusia seluruhnya. ${ }^{30}$

Sebuah konsep "agree in disagreement" dikembangkan oleh Mukti Ali (Cendekiwan Muslim dan Mantan Menteri Agama RI ke-12 tahun 1971-1978). Konsep ini menekankan bahwa setiap mempunyai persamaan dalam tataran sosial dan mempunyai perbedaan dalam tataran teologis. Persamaan dalam tataran sosial hendaknya menjadi perekat antar pemeluk agama karena ternyata setiap agama tidak sepenuhnya berbeda. ${ }^{31}$ Konsep ini pun bisa diperluas sebagai pemersatu antar etnis, suku dan ras, dimana kesemuanya memeliki persamaan yaitu persamaan bangsa dan negara.

Bagi Indonesia, Islam sebagai agama rahmatan lil 'alamin merupakan sebuah kekuatan positif, kreatif, konstruktif, dan inspiratif. Ia mengajarkan bcara menyikapi perbedaan, menciptakan perdamaian dan kedamaian, cinta asih, kasih sayang, persaudaraan, persahabatan dan rasa prikemanusiaan yang mendalam dalam muammalah ma'an $n \bar{a} s^{32}$

\section{Penutup}

Bhinneka Tunggal Ika yang menjadi motto bangsa Indonesia, meskipun tidak lahir dari falsafah keislaman namun jika dikaji lebih dalam ternyata memuat nilai-nilai yang terkandung dalam Islam, sehingga jika seorang muslim merasa anti dengan kebhinekaan tentunya muncul sebuah pertanyaan, apakah dia paham tentang Islam?. Perbedaan

\footnotetext{
${ }^{30}$ Ibid, h. 108-109.

${ }^{31}$ Faisal Ismail, Republik Bhineka Tunggal Ika, h. 10.

32 Ibid, h. 48.
} 
merupakan sebuah fitrah dalam dokrin Islam, sehingga menyikapi perbedaan dengan arif dan bijak merupakan sebuah kewajiban bagi umat Islam agar tidak menimbulkan konflik yang disebabkan perbedaan pandangan. Di Indonesia umat Islam berperan penting dalam menjaga kebhinnekaan yang ada, hal ini dapat dilihat dari berbagai peran umat Islam dalam sejarah bangsa dalam membentuk dan merawat kebhinekaan di Indonesia. Perbedaan-perbedaan yang ada tidak seharusnya disikapi secara negatif, skeptis, atau bahkan anarkis. Perbedaan merupakan sebuah rahmat Allah yang harus disyukuri, sehingga kehidupan ini lebih berwarna dan Indah, dan inilah yang diajarkan agama Islam untuk menciptakan baldatun toyyibah.

\section{Daftar Pustaka}

Ad-Dimasqi, Abul Fida' Ismail bin Umar bin Katsir Al-Qursyi. (1999), Tafsir ul-Qurān al-Adzīm, Darut Taibah, Edisi Maktabah Syamilah.

at-Thabari, Abu Ja'far. (2000) Jami'ul Bayān fī Ta’wīlil Qurān, Muassatur Risalah, Edisi Maktabah Syamilah.

Azhar, Muhammad. (2005) "Epistemologi Islam Kontemporer Sebagai Basis Fikih Kebinekaan”, Fikih Kebinekaan, Bandung: Mizan Pustaka.

Taher, Elza Peldi. (2011), Merayakan Kebebasan Beragama, Jakarta: Democracy Project.

Effendy, Bahtiar. (2011), Islam dan Negara Transformasi Gagasan dan Praktik Politik Islam di Indonesia, Jakarta: Yayasan Abad Demokrasi.

Haidar, M. Ali. (1994), Nahdlatul Ulama dan Islam di Indonesia Pendekatan Fikih dalam Politik, Jakarta: Gramedia Pustaka Utama.

Ismail, Faisal. (2012), Republik Bhineka Tunggal Ika: Mengurai Isu-Isu Konflik, Multikulturalisme, Agama dan Sosial Budaya, Jakarta:Puslitbang Kehidupan Beragama.

Laporan Human Right Watch, (2013), Atas Nama Agama Pelanggaran Terhadap Minoritas Agama di Indonesia, USA: Human Rights Watch.

Mahfudh, KH.MA. Sahal. (1994), Nuansa Fiqih Sosial, Yogyakarta: LKIS.

Mahkamah Konstitusi, Undang-Undang Dasar Republik Indonesia Tahun 1945

Naupal, “Agama dan Kebhinekaan Indonesia: Membaca Peran Agama Sebagai Sistem Pertahanan Kultur dan Harmoni”, makalah FIB UI.

Picard, Michel. (2011), “Agama Adat dan Pancasila”, The Politics of Religion in Indonesia, New York: Routledge.

Porter, Donald J. (2005), Managing Politics and Islam in Indonesia, London:Routledge Curzon,2005. 
Suaedy, Ahmad. M. Dja'far, Alamsyah. Dkk. (2012) Islam dan Kaum Minoritas : Tantangan Kontemporer, Jakarta: the Wahid Institute.

Wanandi, Jusuf. (2002), “ Islam in Indonesia: Its History, Development and Future Challenges", Asia-Pacific Review, vol.9, No.2.

Wahid, Abdurrahman. (2006), Islamku Islam Anda Islam Kita, Jakarta :The Wahid Institute.

https://news.detik.com/kolom/d-3485150/kekalahan-ahok-islam-politik-dan-narasidemokrasi-di-indonesia. 